\title{
The Use of Bevacizumab Alone and in Combination with Classical Chemotheropathics in Ishikawa Endometrial Cancer Cell Culture
}

\author{
Ceren Yıldız Eren ${ }^{1}$ (D) , Hulusi Göktuğ Gürer ${ }^{1}$ (iD , Özlem Özgür Gürsoy ${ }^{1}$ (iD , \\ Ayşe Tansu Koparal ${ }^{2}$ (iD), Sabit Sinan Özalp ${ }^{3}$ (iD
}

${ }^{1}$ Eskisehir Acibadem Hospital, Obstetrics and Gynecology Clinic, Eskisehir, Turkey

${ }^{2}$ Anadolu University Açıköğretim Faculty. Department of Medical Services and Techniques Eskisehir, Turkey

${ }^{3}$ Eskişehir Osmangazi University Department of Obstetrics and Gynecology (retired), Eskisehir, Turkey

Ceren YıIdız EREN, M.D.

Hulusi Göktuğ GÜRER, M.D.

Özlem Özgür GÜRSOY, M.D.

Ayşe Tansu KOPARAL, Prof. Dr.

Sabit Sinan ÖZALP, M.D.

Correspondence: Ceren Yıldız Eren Eskisehir Acibadem Hospital, Obstetrics and Gynecology Clinic, Eskisehir, Turkey

Phone: +905547555050

E-mail: cyeren@yaani.com
Received : 14 April 2021

Accepted : : 21 June 2021

\section{ABSTRACT}

Purpose: The aim of our study is to determine the effects of an antiangiogenic agent (bevacizumab) in combination with or without classic chemotherapeutics on the endometrium carcinoma and use these information in our clinic practice.

Materials and Methods: In vitro tests were done to determine the cytotoxic and apoptotic effects of Cisplatin, Adriablastine and Bevacizumab. Cytotoxic effect was determined by the standard MTT assay (Tetrozolium Test) and apopthosis by DAPI staining, caspase-3 on human endometrium cancer cell culture (Ishikawa).

Results: The MTT assay determined that $9.6 \mathrm{mg} / \mathrm{ml}$ dose of bevacizumab caused a higher rate of decrease in cell number on Ishikawa cells compared to the highest doses of Cisplatin and Adriablastine. Therewithal, when Bevacizumab, Cisplatin, and Adriablastine were applied together for 24 hours, the number of cells decreased with an increasing dose. With the use of the triple combination with DAPI staining, it is seen that the cell silhouettes are effaced and the findings indicating apoptosis become more apparent. When bevacizumab was applied alone, the caspase 3 activity it produced was ascertained to be higher than the other two drugs individually and in combination. Caspase-3 activity was ascertained to have increased significantly as a result of the collective usage of $40 \mu \mathrm{M}$ Cisplatin $+20 \mu \mathrm{M}$ Adriablastine $+9.6 \mu \mathrm{gram} / \mathrm{ml}$ Bevacizumab, and this was found to be the highest cytotoxic activity compared to other applications.

Conclusion: Bevacizumab has significant anticancer activity alone or in combination with other chemotherapeutics.

Keywords: Endometrial carcinoma, angiogenesis, VEGF, Ishikawa, apoptosis.

Ishikawa Endometrial Kanser Hücre Kültüründe Bevacizumabin Tek Başına ve Klasik Kemoteropatiklerle Birlikte Kullanımı

ÖZET

Amaç: Çalışmamızın amacı anti anjiogenik ajanların (bevacizumab) endometriyum kanserinde klasik kemoterapilerle kombine ve tek başına kullanımlarının etkilerini araştırmak ve klinik pratiğe yansıtmaktır.

Gereç ve Yöntem: Cisplatin, Adriablastin, Bevacizumab kombinasyonlarının sitotoksik ve apoptotik etkilerini saptamak için in vitro testler yapılmıştır. Bunun için Ishikawa (insan endometriyum kanser hücresi) hücre kültürü üzerinde sitotoksik etkiyi belirlemek için MTT testi (Tetrozolium Testi), apoptosizi saptamak için ise DAPI boyama, caspase-3 testi kullanılmıştır.

Bulgular: Bevacizumabın 9,6 mg/ml'ık dozunun Ishikawa hücreleri üzerinde Cisplatin ve Adriablastinin en yüksek dozlarına göre hücre sayısında daha yüksek bir oranda düşüşe neden olduğu MTT testi ile belirlenmiştir. Aynı zamanda Bevacizumab, Cisplatin ve Adriablastininin 24 saat birlikte uygulandığında doz artışı ile hücre sayısında azalma meydana gelmiştir. DAPI boyama ile üçlü kombinasyonun kullanımı ile hücre silüetlerinin silindiği ve apoptozisi gösteren bulguların daha bariz hale geldiği görülmektedir. Bevacizumab tek başına uygulandığında oluşturduğu kaspaz 3 aktivitesi diğer iki ilacın tek tek ve ikili kombinasyonundan daha yüksek bulunmuştur. $40 \mu \mathrm{M}$ Cisplatin $+20 \mu \mathrm{M}$ Adriablastin $+9,6 \mu \mathrm{gram} /$ ml Bevacizumabın birlikte uygulanması sonucunda kaspaz-3 aktivitesinin önemli ölçüde artış gösterdiği saptanmış ve bu diğer uygulamalarla kıyaslandığında en yüksek sitotoksik aktivite olarak bulunmuştur.

Sonuç: Bevacizumab yalnız başına veya diğer kemoterapötüklerle birlikte önemli antikanser etkiye sahiptir.

Anahtar Kelimeler: Endometrium kanseri, angiogenezis, VEGF, Ishikawa, apoptosiz. 
E ndometrium carcinoma is the most common malignant tumor of the female genital tract and ranks seventh in most cancer-related deaths (1). It has been ascertained that the lifetime possibility of developing endometrial cancer for women is $2-3 \%$ in the whole population (2). The average age at diagnosis is 60. (3).

Curative and primary treatment in endometrial cancer is surgery $(4,5)$. The most actively used chemotherapeutic agents are doxorubicin, paclitaxel, cisplatin, and carboplatin (6). Most of the responses obtained with these agents are partial and usually average three-six months, with median survival ranging from 4 to 8 months in recurrent cases (7).

Cancer is modern day's deadly disease, the answer to which is hidden deep within cell biology. Today, studies have shown that the results obtained from cell culture tests are more realistic and specific to investigate the possibility of any drug. (8).

Gynecological oncology is one of the new application areas of these new agents and treatment strategies. Various target treatments are also being tried in endometrial cancer. One of them is antiangiogenic agents (9).

If the tumors cannot produce new vessels, they are fed by diffusion from the surrounding vessels and can grow up to a maximum volume of $0.5-1 \mathrm{~cm} 3$. Angiogenesis is required for proliferation and metastasis after this volume (10).

Vascular Endothelial Growth Factor (VEGF) is the most important and most emphasized one in tumor-related angiogenesis studies. Among the primary targets, VEGF receptors are the most preferred.

One of the monoclonal antibodies against VEGF, rhuMab VEGF (Bevacizumab, [Avastin ${ }^{\mathrm{TM}}$ ] Genentech, South San Francisco, California USA) is a recombinant human monoclonal VEGF antibody with anti-angiogenic and antitumor activity (11). Also, in randomized phase III studies, when combined with standard chemotherapeutics in patients with metastatic colorectal cancer, compared to conventional therapy, it was found that patients had a significant increase in survival, a significant decrease in tumor progression, and no increase in thromboembolic complications (12).

The aim of our study is to determine the effects of bevacizumab alone and in combination with classic chemotherapeutics on the endometrium carcinoma and use these information in our clinic practice.

\section{MATERIALS AND METHODS}

Ishikawa cells were provided by Istanbul University Çapa Faculty of Medicine academic staff member Prof. Dr. Ayhan Bilir. Ishikawa cells, DMEM / F12 (1: 1) (Sigma Aldrich Chemical Co, USA) containing ten\% Fetal Bovine Serum, penicillin-streptomycin (Sigma Aldrich Chemical Co, USA), were grown by culturing in a medium containing sodium bicarbonate at $370 \mathrm{C}$ in an environment containing five $\%$ $\mathrm{CO} 2$. As a result of DAPI staining applied after obtaining the cells, it was examined under a fluorescent microscope.

The doses were prepared by mixing Bevacizumab (Altuzan) (Roche) directly into the medium. Cisplatin (Sigma Aldrich Chemical Co, USA), Adriablastine (Sigma Aldrich Chemical Co, USA), Dimethyl Sulfoxide (DMSORiedel de Haen). The doses were prepared by dissolving the medium (1:40). Doses were used as soon as they were prepared.

In Vitro Cytotoxicity Test (MTT Assay)

To determine the cytotoxic effects of Cisplatin, Adriblastine, and Bevacizumab, effective doses were determined by performing an MTT [3-(4,5-dimethylthiazol2-yl)-2,5-diphenyl tetrazolium bromide] (Sigma Aldrich Chemical Co, USA) assay on Ishikawa cells.

For this purpose, the viability of the grown cells was determined by Trypan Blue staining, then the cells were counted with Thoma slide, and they were cultivated in 96-well plates at $2 \times 10^{4}$ per well and cultured for 24 hours. At the end of 24 hours, the medium in the wells was emptied and the media containing different concentrations of test substances were placed in the plates. The media were removed from the cells treated with test substances for a certain period at the end of the incubation period. The cells were incubated for two hours with five $\mathrm{mg} / \mathrm{ml}-1$ MTT solution to convert the MTT dye into water-insoluble formazan salt as a result of mitochondrial metabolic activities of living cells. At the end of this period, MTT dye was 
removed from the cells. $0.1 \mathrm{ml}$ DMSO was added to each well to dissolve the formazan salts formed by living cells. Optical densities of the cells in the plates were measured in an ELISA at a wavelength of $570 \mathrm{~nm}$. Viability rates of test cells are expressed as a percentage, assuming the control cell viability rate not treated with test substance as $100 \%$. The experiments in which the cells were planted in parallel eight for each test substance dose in the experiment sets were repeated three times independently from each other. SPSS program was used in the statistical evaluation of the results of MTT experiments and the significance of the obtained data was determined by applying one-way ANOVA and Tukey test as a post-hoc. $P<0.05$ was accepted as the significance value.

For the detection of apoptosis, morphological examination (DAPI Staining) with fluorescent staining was performed and the Caspase-3 test was used.

\section{Morphological Examination with Fluorescent Staining (DAPI Staining)}

DAPI (Sigma Aldrich Chemical Co, USA) staining was performed to determine whether the doses of Cisplatin, Adriablastine, and Bevacizumab determined as a result of the MTT assay had an apoptotic effect on Ishikawa cells. Cells inoculated into six-well plates with sterile round coverslips were cultured for 24 hours in a $\mathrm{CO}_{2}$ incubator. At the end of this period, the medium in the wells was removed and the effective doses determined as a result of the cytotoxicity tests of the substances were applied to the cells adhering on the coverslip for 12 hours. After 12 hours, the medium was removed from the wells, and the coverslips were washed with sterile phosphate buffer solution (PBS: $137 \mu \mathrm{M} \mathrm{NaCl}, 2.7 \mu \mathrm{M} \mathrm{KCl}, 15 \mu \mathrm{M} \mathrm{KH} 2 \mathrm{PO} 4,8 \mu \mathrm{M}$ NaHPO4; PH 7.3), with 3.7\% paraformaldehyde solution dissolved in PBS.
They were determined for 15 minutes at $37 \mathrm{oC}$. After the fixation process, coverslips were washed three times with PBS and incubated for 30 minutes at $37 \mathrm{oC}$ with one $\mathrm{mg} /$ mI DAPI (4'6-diamidino-2 phenylindole) in the dark environment. The coverslips were then covered by washing with PBS and examined under a fluorescent microscope and photographs were taken.

\section{Caspase-3 assay}

Cells were lysed to collect their cell contents (Chemicon APT165). As a result of the experiment, the plates were scanned with an Eliza microplate reader at a wavelength of $405 \mathrm{~nm}$ (R\&D systems, Inc. 1-800-343-7475). SPSS program was used in the statistical evaluation of the results, and the significance of the obtained data was determined by applying one-way ANOVA and post-hoc Tukey test. P $<0.05$ was accepted as the significance value.

\section{RESULTS}

\section{MTT Assay Results}

Researchers have reported that $20 \mu \mathrm{M}$ dose of cisplatin is effective in MTT studies (13). For this reason, 20, 40 and 80 $\mu \mathrm{M}$ doses of cisplatin were selected in MTT experiments.

The $20 \mu \mathrm{M}$ dose of Cisplatin caused cell proliferation by an $11 \%$ decrease on the first day, and $49 \%$ on the second day. The $80 \mu \mathrm{M}$ dose of cisplatin caused a $45 \%$ decrease in cell count on the first day and $87 \%$ on the second day (Figure 1).

Adriablastine $0.625 \mu \mathrm{M}$ dose reduced cell proliferation by $19 \%$ on the first day and $44 \%$ on the second day. The highest dose of Adriablastine, $160 \mu \mathrm{M}$, caused cell proliferation todecrease by $76 \%$ on the first day and $88 \%$ on the second day (Figure 1).
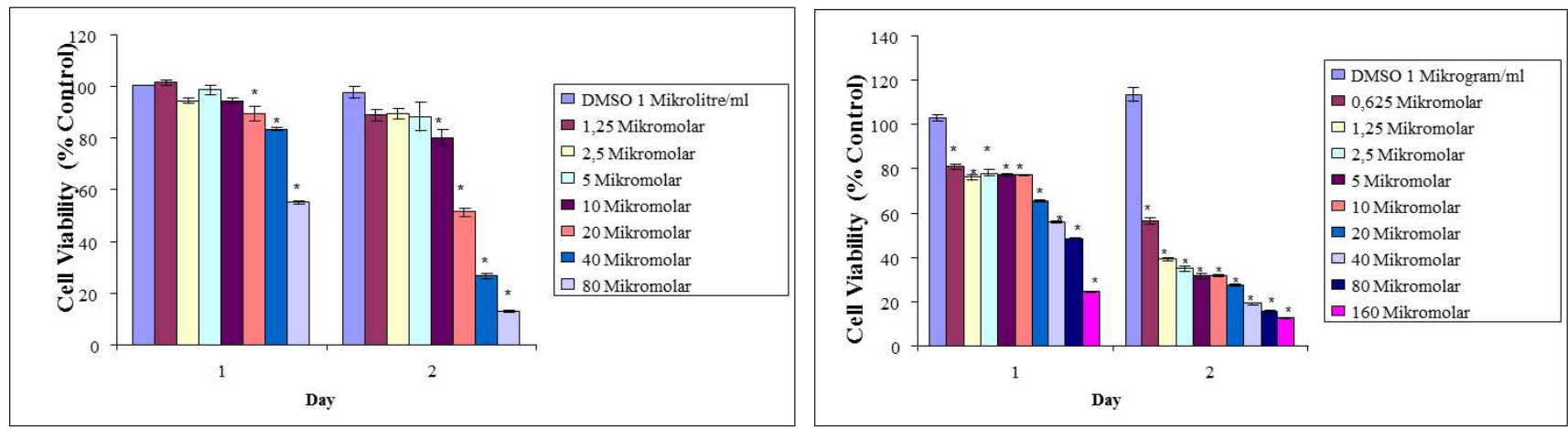

Figure 1. Effects of Cisplatin Adriablastine and on Ishikawa cells by MTT test $\left(^{*}\right)$ sign shows significant differences compared to the control group $(\mathrm{p}<0.05)$. 


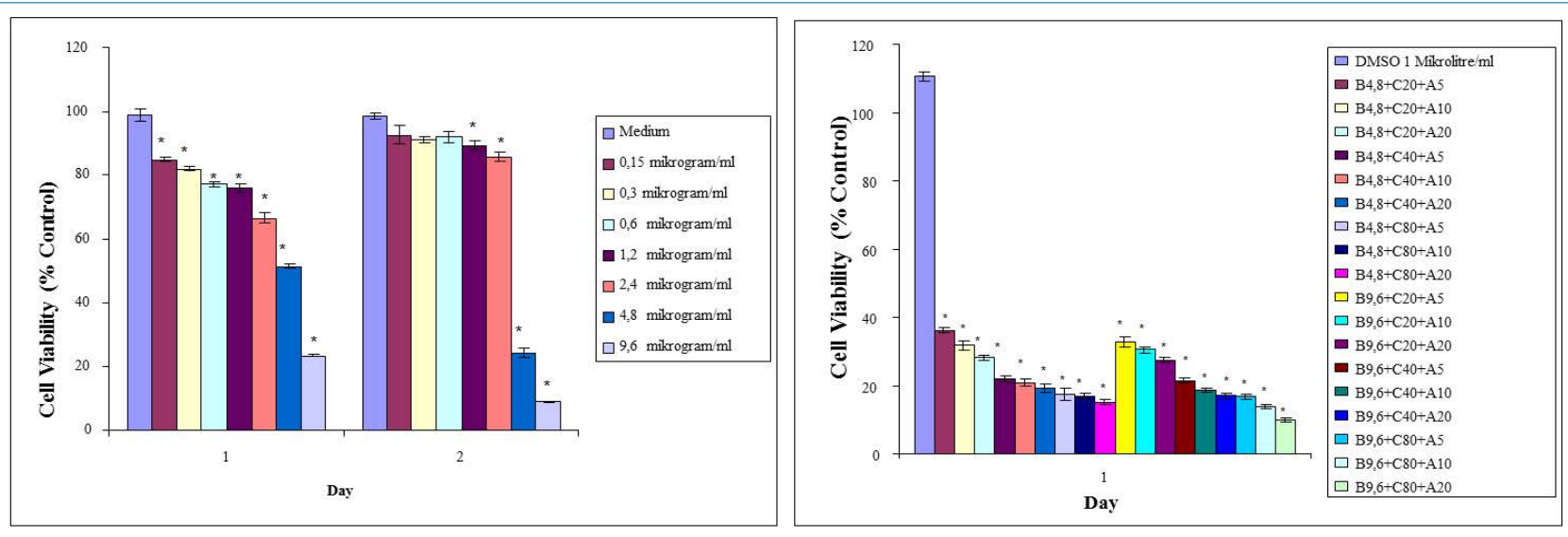

Figure 2. Effects of Bevacizumab and co-administration of different doses of Bevacizumab, Cisplatin and Adriablastin on Ishikawa cells by MTT test $\left(^{*}\right)$ sign shows significant differences compared to the control group $(p<0.05)$.

Bevacizumab doses of $0.15,0.3,0.6,1.2$ and $2.4 \mathrm{mg} / \mathrm{ml}$ caused a decrease in cell number on Ishikawa cells on the first day, while the second day caused a lesser decrease in cell number compared to the first day. It was determined by the MTT assay that a $9.6 \mathrm{mg} / \mathrm{ml}$ dose of bevacizumab caused a higher rate of decrease in cell number on Ishikawa cells compared to the highest doses of Cisplatin and Adriablastine (Figure 2).

A dose-dependent effect was observed on the number of Ishikawa cells when cisplatin and Adriablastine were co-administered for 24 hours. At the same time, a dose-dependent effect was observed in the number of cells in Ishikawa cells where Bevacizumab, Cisplatin and Adriablastine were administered together for 24 hours. The number of cells decreased with the increase in dose. It has been determined that triple combination application prevents cell proliferation more effectively than Cisplatin and Adriablastine application (Figure 2).

\section{DAPI Staining Results}

In order to morphologically determine the apoptotic effects of Cisplatin, Adriablastine and Bevacizumab alone and together on Ishikawa cells, doses found to be effective as a result of the MTT assays were applied to the cells, followed by DAPI staining. Arrows in photographs of Ishikawa cells where Cisplatin, Adriablastine and Bevacizumab were administered alone and together indicate apoptotic cells. In apoptotic cells, it has been observed that the cell nuclei are divided into small pieces, strangulation occurred in the nuclei and the nuclei are condensed. There was no change in cell morphology with DMSO, that is, the solvent applied to Ishikawa cells. In Ishikawa cells where 20, 40 and $80 \mu \mathrm{M}$ doses of cisplatin were applied for 12 hours, it was observed that fragmentation in the cell nuclei increased depending on the dose.
It was found that the number of apoptotic cells was not high in the DAPI staining results, which serve to show the preapoptotic effect when compared to the control group at doses of five, 10, $20 \mu \mathrm{M}$ of Adriablastine. At both doses of bevacizumab that were found to be effective with MTT, it was observed that fragmentation in the cell nucleus increased depending on the dose. In combination of Adriablastine and cisplatin, and especially in the combination of Adriablastine, Cisplatin and Bevacizumab, it is seen that the cell silhouettes are erased and the findings indicating apoptosis become more pronounced (Figure 3).

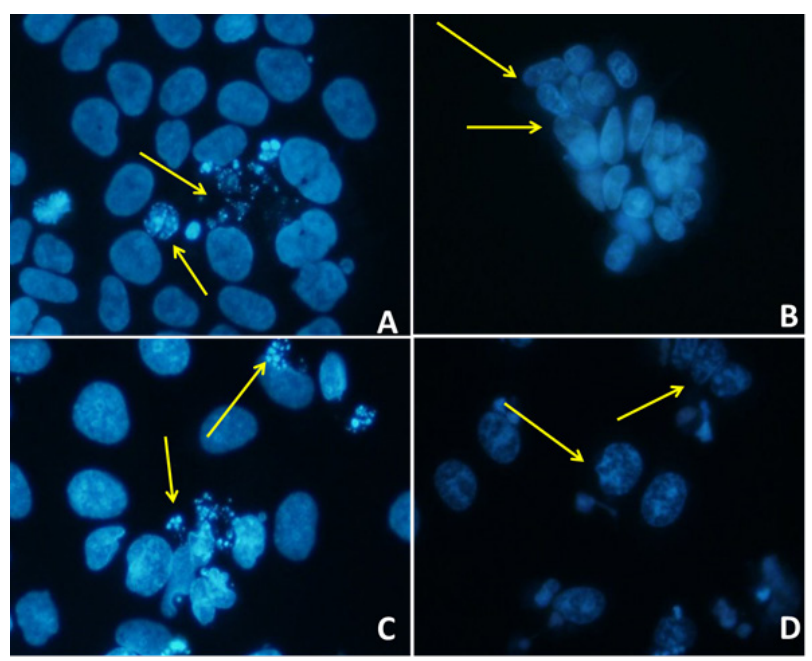

Figure. 3. DAPI staining of Ishikawa cells. A. Cisplatin $80 \mu \mathrm{M} ; \mathrm{B}$. Adriablastin $20 \mu \mathrm{M}$; C. Bevacizumab $9.6 \mu \mathrm{g} / \mathrm{ml}$; D. Bevacizumab 9,6 $\mu \mathrm{g} / \mathrm{ml}+$ Cisplatin $4040 \mu \mathrm{M}+$ Adriablastin $20 \mu \mathrm{M}$

\section{Caspase-3 Results}

High caspase 3 activity is an indicator of irreversible apoptosis (14). After treatment of Ishikawa cells with drugs for 
12 hours, caspase 3 activity was measured by fluorimetric method. The effects of Cisplatin, Adriablastine and Bevacizumab alone and together on the caspase 3 activities of Ishikawa cells are observed in Figure 4 . The caspase 3 activity created by bevacizumab alone was found to be higher than the single and double combination of the other two drugs. As a result of the co-administration of $40 \mu \mathrm{M}$ Cisplatin $+20 \mu \mathrm{M}$ Adriablastine $+9.6 \mu \mathrm{gram} / \mathrm{ml}$ Bevacizumab, a significant increase in caspase- 3 activity was found, and this was found to be the highest compared to the others. The caspase- 3 results of drugs administered alone are lower than when the three are administered together.

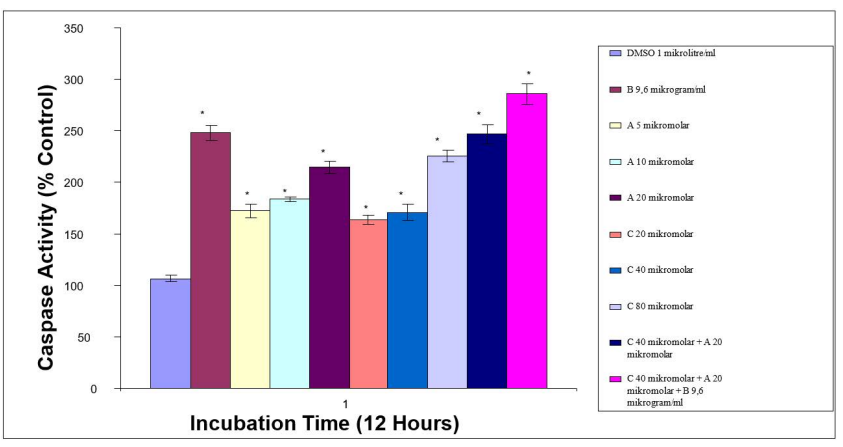

Figure 4. Caspase-3 results. Ishikawa cells 12-hours treatment with Cisplatin (C), Adriablastin (A) and Bevacizumab (B) alone and combination. Control cells were treated with DMSO. The $\left.{ }^{*}\right)$ sign indicates significant differences compared to the control group ( $p$ $<0.05)$.

\section{DISCUSSION / CONCLUSION}

Endometrial cancer is usually diagnosed at an early stage and is considered a benign cancer. Chemotherapy in endometrium cancer comes to the fore especially in the treatment of advanced stage and recurrent disease. The most commonly used agents for this purpose are Doxorubicin, Cisplatin and Paclitaxel $(15,16)$.

However, in advanced stage or recurrent endometrial cancer, the average response rate of Doxorubicin Cisplatin combination is $45-63 \%$, and the response rate to doxorubicin alone is $19-27 \%$ (17). Single agent paclitaxel can also be used in patients with advanced stage endometrial cancer, but the average response rate is $36 \%$ (18). In the study conducted by Fleming et al., the average response rate was found to be $46 \%$ in patients with advanced stage endometrial cancer who received doxorubicin, Cisplatin and paclitaxel combination therapy (19).
If endometrial cancer is recurrent or metastatic, the prognosis is poor. In the studies of the Gynecological Oncology Group, the average survival with hormonotherapy or chemotherapy was generally found to be one year or less (20). Various cytotoxic agents are effective in the treatment of recurrent endometrial cancer. However, the general age of this patient group, previous pelvic radiotherapy exposure and the presence of comorbidities such as obesity, hypertension, and diabetes mellitus increase the morbidity and mortality of chemotherapy (21). In the GOG study published in 2004, the average age of the patients participating in the study was found to be 65 , and this group had a history of pelvic radiotherapy at a rate of $68 \%$ (22).

The methods applied using the cell culture technique is fast and reproducible in drug research and development studies. For this reason, these methods are used extensively to determine the effectiveness of new drug candidates developed by the pharmaceutical industry against cancer. In this study, a cell culture study was designed to examine the use of bevacizumab, which is known to have antiangiogenetic effects in endometrial cancer, alone or in combination with other chemotherapeutics, and the in vitro drug effects were examined.

Inhibition of apoptosis is one of the steps in cancer development. Cancer cells die with apoptosis in response to chemotherapy and radiotherapy. However, in the late stages of the disease, there is a resistance to apoptosis, which leads to treatment failure. Therefore, initiation of effective apoptosis activation in cancer cells has gained importance in treatment strategies. In studies, demonstration of apoptosis and cytotoxicity is necessary to demonstrate the efficacy of treatment. In the detection of apoptosis, DAPI staining is used as an indicator for determining nucleus size and morphology. While DAPI experiments showed that the use of bevacizumab alone and in combination has pre-apoptotic effects, it was found as a result of the Kaspaz-3 tests that the use of Bevacizumab alone or together was more effective on Ishikawa cells.

There are studies revealing the in vivo efficacy of bevacizumab. In the retrospective study of Rose et al., it was found that there was a high response to the combined use of bevacizumab, paclitaxel, and carboplatin in the treatment of advanced stage and recurrent endometrial carcinoma, resulting in a significant difference in survival rates (23).

However, in the MITO END-2 study of Lorusso et al., the use of bevacizumab in combination with chemotherapy in the treatment of advanced stage or recurrent endometrial carcinoma did not show a significant effect on survival (24). 
As a result of the meta-analysis of Chen et al., it was revealed that chemotherapy combined with bevacizumab had a high effect on disease-free survival and recovery rates on patients with advanced stage or recurrent endometrial cancer (25).

A prospective multicenter observational study was conducted in Japan on the subject. The efficacy and safety of bevacizumab-paclitaxel combination therapy as first- or second-line chemotherapy for metastatic breast cancer has been studied. Multivariate analyses were conducted to identify prognostic factors. According to the results of the study, combined bevacizumab-paclitaxel is very effective. This effectiveness is as remarkable as in former studies (26).

Glioblastoma is one of the most aggressive tumors in adults. Median survival is 20.9 months. In one study, bevacizumab was used in a cohort of 1082 glioma patients to determine whether bevacizumab could increase the anti-angiogenic effect. Found that anti-angiogenic effect (VEGFA expression levels) the response to treatment in cell culture. This data indicate that bevacizumab can improve clinical results in Glioblastoma therapy (27).

The cytotoxic effect of bevacizumab and other VEGF antibodies on cancer cells has been proven in many in vivo and in vitro studies as in our study. Considering that it has fewer side effects compared to conventional chemotherapeutics, its use in primary care in the treatment of endometrial cancer should be kept in mind. Combination with classical chemotherapeutics used especially in advanced stage disease is a promising treatment approach.

The most important challenge in cancer therapy nowadays is the lack of anticancer medication with great efficaciousness, broad-spectrum and minimum side effects. It is accepted that this question can be solved with combination treatment. It is considered that the results obtained in this study strengthen this focus.

\section{Acknowledgment}

This article is produced from our thesis. We would like to thank the Hulusi Göktuğ GÜRER and Özlem Özgür GÜRSOY. They took part in the preparation of the article for publication.

\section{REFERENCES}

1. Marcus D, Savage A, Balog J, Kudo H, Abda J, Dina R, et al. P74 Endometrial cancer: Can the iKnife diagnose endometrial cancer? Int J Gynecol Cancer. 2019;29:A100-A101

2. Siegel RL, Miller KD, Jemal A. Cancer Statistics. 2017; 67(1): 7-30.

3. Morice P, Leary A, Creutzberg C, Abu-Rustum N, Darai E. Endometrial cancer. The Lancet. 2016;387:1094-108.

4. Lu KH. Management of early stage endometrial cancer. Semin Oncol. 2009;36:137-44.

5. Hogberg T.Adjuvant chemotherapy in endometrial carcinoma:overview of randomized trials.Clin Oncol ( $R$ Coll Radiol).2008;20:463.

6. Aghajanian C, Filiaci V, Dizon DS, Carlson JW, Powell MA, Alvarez Secord A, et al. A Phase II Study of frontline paclitaxel/carboplatin/ bevacizumab, paclitaxel/carboplatin/temsirolimus, or ixabepilone/ carboplatin/bevacizumab in advanced/recurrent endometrial cancer. Gynecol Oncol. 2018;150:274-81.

7. Howlader, N; Noone, AM; Krapcho, M, et al. SEER cancer statistics review, 1975-2012. National Cancer Institute. 2014.

8. Shay, Jerry \& Wright, Woodring. Shay JW, Wright WEHayflick, his limit, and cellular ageing. Nat Rev Mol Cell Biol. 2000;1:72-76.

9. Delmonte $A$,Sessa C. Moleculer targeted agents in endometrial carcinoma:overview of randomised trials.Clin Oncol ( $R$ Coll Radiol.) 2008; 20: 554.

10. Bates DO, Hillman NJ, Williams B et al. Regulation of microvascular permeability by vascular endothelial growth factors. J Anat. 2002; 200: 587-597.

11. Minami $H$, Ebi $H$, Tahara $M$ et al. A phase I study an oral VEGF receptor tirozin kinaz inhibitor ZD6474 in Japanese patients with solid tumors. Proc Am Soc Clin Oncol 2003; 22: 194

12. Trarbach T, Shleucher N, Riedel U et al. Phase I/II study of the oral vascula ebdothelial growth factor (VEGF) receptor inhibitor PTK787/ZK222854 in combination with irinotecan/5-fluorouracil/ leucoverin in patients with metastatic colorectal cancer. Proc Am Soc Clin Oncol. 2003; 22:285

13. Zhuo, W., Wang, Y., Zhuo, X., Zhang, Y., Ao, X., Chen, Z., (2008), Knockdown of Snail, a novel zinc finger transcription factor, via RNA interference increases A549 cell sensitivity to cisplatin via JNK/ mitochondrial pathway. Lung Cancer. 2008; 62: 8-14.

14. Caruso, F., Villa, R., Rossi, M., Pettinari, C., Paduano, F., Pennati, et al. Mitochondria are primary targets in apoptosis induces by the mixed phosphine gold species chlorotriphenylphosphine-1,3 bis(diphenylphosphino) propanegold(I) in melanoma cell lines, Biochemical Pharmacology. 2007; 73: 773-781.

15. Bruzzone M, Miglietta L, Franzone P, Gadducci A, Boccardo F. Combined treatment with chemotherapy and radiotherapy in high-risk FIGO stage III-IV endometrial cancer patients. Gynecol Oncol. 2004;93:345-352.

16. Homesley HD, Filiaci V, Gibbons SK, et al. A randomized phase III trial in advanced endometrial carcinoma of surgery and volume directed radiation followed by cisplatin and doxorubicin with or without paclitaxel: a Gynecologic Oncology Group study. Gynecol Oncol. 2009;112:543-552.

17. Thigpen JT, Brady MF, Homesley HD, et al. Phase III trial of doxorubicin with or without cisplatin in advanced endometrial carcinoma: a Gynecologic Oncology Group study. J Clin Oncol. 2004;22:3902-3908.

18. Sreedevi MS, Pavan KK, Neelakantan A. Carboplatin and paclitaxel: Role in the treatment of endometrial cancer Editor(s): Rama RM, Ganji PN. A Theranostic and Precision Medicine Approach for Female-Specific Cancers, Academic Press, 2021. p. 165-177. 
19. Fleming GF,Fowler JM,Waggoner SE,et al.Phase 1 trial of escalating doses of paclitaxel combined with fixed doses of cisplatin and doxorubisin in advanced endometrial carcinoma and other gynecologic malignencies: a Gynecologic Oncology Group Study. J Clin Oncol. 2001;19:1021-1029.

20. Randall ME, Filiaci VL, Muss $\mathrm{H}$, et al. Randomized Phase III trial of whole-abdominal irradiation versus doxorubicin and cisplatin chemotherapy in advanced endometrial carcinoma: a Gynecologic Oncology Group study. J Clin Oncol. 2006;24:36-44.

21. Mariani A, Dowdy SC, Cliby WA, et al. Prospective assessment of lymphatic dissemination in endometrial cancer: a paradigm shift in surgical staging. Gynecol Oncol. 2008; 109(1): 11-18

22. J.Tate Thigpen, Mark F. Brady, Howard D. Homesley, John Malfetano, Brent DuBeshter, Robert A. Burger, Shu Liao Phase III Trial of Doxorubicin With or Without Cisplatin in Advanced Endometrial Carcinoma: A Gynecologic Oncology Group Study. Journal of Clinical Oncology. 2004;22(October 1): 3902-3908.

23. Rose PG, Ali S, Moslemi-Kebria M, Simpkins F. Paclitaxel, carboplatin, and bevacizumab in advanced and recurrent endometrial carcinoma. Int J Gynecol Cancer. 2017;27:452-58.

24. Lorusso D, Ferrandina G, Colombo N, Pignata S, Pietragalla A, Sonetto C, et al. Carboplatin-paclitaxel compared to carboplatinpaclitaxel-bevacizumab in advanced or recurrent endometrial Cancer: MITO END-2-A randomized phase II trial. Gynecol Oncol 2019;155:406-12

25. Chen, Hui, Minglin Liang, and Jie Min. Efficacy and Safety of Bevacizumab-Combined Chemotherapy for Advanced and Recurrent Endometrial Cancer: A Systematic Review and Metaanalysis. Balkan medical journal. 2021;38:7-12.

26. Yamamoto $\mathrm{Y}$, Yamashiro H, Toh U. et al. Prospective observational study of bevacizumab combined with paclitaxel as first- or secondline chemotherapy for locally advanced or metastatic breast cancer: the JBCRG-C05 (B-SHARE) study. Breast Cancer. 2021; 28: 145-160.

27. García-Romero N, Palacín-Aliana I, Madurga R. et al. Bevacizumab dose adjustment to improve clinical outcomes of glioblastoma. BMC Med. 2020; 18: 142. 